\title{
Potential Existence of Heavy Metal Pollution and Pesticide in Honey-based Products
}

\author{
Dg Nooralizan Abd Wahid, Wan Fahmi Wan Mohamad Nazarie, Roslina Jawan, Rahmath Abdulla, Jualang Azlan \\ Gansau and Mohd Khalizan Sabullah*
}

Faculty Science and Natural Resources, University Malaysia Sabah

* Correspondence: khalizan@ums.edu.my

\begin{abstract}
Simple Summary: Honey bees provide nutritious honey that helps in maintaining our good health. Besides honey, honey bees also produce several honey-based products such as pollen, beeswax, beebread and propolis. Honey bees also help humans in agriculture field because they are an excellent pollinator for plants. Honey contains approximately 45 minerals in general. Some of them are useful when used in the proper dosage, while others can cause serious toxicity in humans. This toxicity can happen if the honey is exposed to heavy metals pollution. Anthropogenic pollution, such as industrial and agricultural wastes is the factor that causes toxic effects to bees and their products. Therefore, the aim of this paper is to review the potential existence of heavy metal pollution as well as pesticide in honey-based products from the available literature. However, to not endanger consumers, more detailed studies are needed to maintain the quality of bee products so that the nutrients contained in the products are unperturbed.
\end{abstract}

\begin{abstract}
Over the centuries, honey is known for its superior usage in culinary, and for its rich nutrition and therapeutic values which are scientifically proven in the medical field. The chemical composition of honey varies depending on its botanical sources and environment. Therefore, the nutrition content in honey is highly likely to be affected by contaminants, such as heavy metals and pesticides. To ensure the quality of honey, parameters such as the heavy metal content should be within the safe range of total standard mineral and trace elements as defined by the International Food Standard (Codex Alimentarius), and pesticides should not be present at all. The high concentration of heavy metal and pesticides not only deteriorates the quality and quantity of honey, but also causes harm to the bee colony itself. In the agriculture sector, the excessive usage of pesticides and fertilizer negatively impacts the overall honey production process. Bees, a pollinating agent, bring the polluted nectar back to their beehives, eventually contaminating the honey and depreciating its value. Hence, this article will comprehensively review the activities that contribute to heavy metal and pesticide contamination, the interactions of bees as a pollinating agent, the impact of the pollutant to the colonies, and subsequently to the honey production.
\end{abstract}

Keywords: heavy metal; pesticides; honey bee; trace elements

\section{Introduction}

Since time immemorial, honey was widely used not only as a natural sweetener but also traditionally utilised as a remedy for diseases like stomach-ache, cough, and disinfectant [1]. In terms of modern medicine, it has been confirmed that the existence of several compounds and elements in honey are capable of treating many other diseases like asthma, wound, neurological diseases, diabetes, cardiovascular diseases, gastrointestinal problems and cancer $[1 ; 2 ; 3]$. Moreover, previous studies have proved that honey has its virucidal effect on enveloped viruses like HIV, herpes simplex, influenza virus, and varicella-zoster virus $[4 ; 5 ; 6]$ and the current study shows that honey can treat novel coronavirus (COVID-19) and reduce the severity of pulmonary inflammation for COVID-19 patients $[7 ; 8]$. 
Bees produce nutritious honey that is beneficial to the human body by supplying various nutrients needed in the body's metabolism, strengthening the body's immunity, and helps in production of antibodies. Honey is rich in antioxidants that help maintain cell function and cell activity [9]. Antioxidants plays an important role in repairing and stabilizing chemical bonds by releasing electrons to free radicals. In addition, the phytochemical compounds present in honey also has medicinal properties that can act as anti-microbial, anti-parasitic, anti-diabetic (which helps reduce glucose in the blood), anti-inflammatory, wound healing agent, anti-cancer, and can also prevent cardiovascular diseases [2;10]. Honey is also often used in cosmetics and skincare products because the nutrients found in honey may help repair the skin barrier structure and inhibit the formation of excessive oxidative stress. Usually, honey and beeswax are two bee products used in the beauty industry in the skin and cosmetics products as toners and softeners to treat skin tissues, facial cleansers, facial scrubs, and masks. [10;11]. Besides that, propolis is one of the honey products studied by many scientists due to its active compounds. This is because propolis has pharmacological properties, such as anti-hepatotoxic, anti-tumor, anti-oxidative, anti-microbial, and anti-inflammatory.

Besides nutritious honey, bees help in forest sustainability through environmental conservation by pollination activities, which also helps the agricultural sector to increase agricultural products that can contribute to ecotourism development [12] and maintain the ecosystem. They can carry many pollen grains on their hairy bodies and rely on flowering plant species that make bees effective pollinators even though bees are not the most diverse group of pollinators [13]. Bees are included in the social group of Hymenoptera insects. In Malaysia, there are several types of bee species that catch the attention of beekeepers or producers in honey production. They belong to the genus Apis spp, such as $A$. dorsata, A. mellifera, and A. cerana, which were known as honey bees. At the same time, the stingless bee from the tribe Meliponin also increased in terms of sales popularity.

The bioactive compounds, minerals and trace elements that constitute honey products can be contaminated by heavy metals occurring in the environment, directly affecting the quality of bee products. Heavy metals contamination may disrupt the activity of the bee colony. Thus, bees can be used as a subject for various studies related to the environment, and considered as an ideal bioindicator to determine the level of environmental quality.

\section{The importance of chemical elements in the human body}

In general, the human body has at least 60 chemical elements. Nevertheless, only 25 of them play an important role in human health $[14,15]$. These chemical elements can be classified into three groups based on the body's needs: macroelements, trace elements, and ultra-trace elements. Macroelements or also known as macrominerals are needed in large quantities while elements required in small quantities are known as microminerals. Excess intake of microminerals may be toxic to the human body. Other than that, there are also unnecessary elements which are toxic and unbeneficial to humans. Table 1 shows the concentration of elements required in the human body. 
Table 1. The concentration of mineral required in the human body.

\begin{tabular}{ccc}
\hline Mineral & Elements & $\begin{array}{c}\text { The concentration required } \\
\text { by human body per day }\end{array}$ \\
\hline Major elements & $\begin{array}{c}\text { Sodium, potassium, calcium, } \\
\text { magnesium, phosphorus, } \\
\text { chlorine }\end{array}$ & $>50 \mathrm{mg} / \mathrm{day}$ \\
Trace elements & $\begin{array}{c}\text { Iron, iodin, fluorine, zinc, } \\
\text { selenium, copper, manga- } \\
\text { nese, chromium, molyb- } \\
\text { denum, cobalt and nickel }\end{array}$ & $<50 \mathrm{mg} / \mathrm{day}$ \\
\hline Aluminum, arsenic, barium, \\
bismuth, boron, bromine, \\
cadmium, lithium, cesium, \\
germanium, mercury, lead, \\
tin, samarium, rubidium, \\
antimony, silicon, strontium, \\
thallium, titanium, tungsten
\end{tabular}

Trace elements are needed as catalysts in enzyme systems. Some of metal ions like iron and copper are involved in oxidation-reduction reactions in energy metabolism. For example, iron constitutes haemoglobin and myoglobin that are critical in oxygen transport. In comparison, copper is required to carry out biochemical and physiological functions. Copper has unique abilities in several different redox reactions, such as oxidation $\left(\mathrm{Cu}^{2+}\right)$ and reduction $\left(\mathrm{Cu}^{+}\right)$. Copper also functions as a cofactor in enzyme reaction associated with oxidative stress.

The low copper concentration in the human body can interfere in the biochemical function of the body. In pregnant women, its deficiency can cause neurological and immunological ailment, increased risk of osteoporosis, disruption of melanin synthesis, weak immune system that increases the rate of infection, cardiovascular disease that leads to changes in the cholesterol metabolism, and iron mobilization disturbance; and affect the bone formation during the development of the baby [16,17]. However, an excessive amount of copper in the body can also negatively impact the body, causing severe toxicity at the biomolecular and cellular levels, eventually leading to death. This copper toxicity occurs due to copper contamination in water and food sources [18]. Based on nutrient intake recommendations or RDA (Recommended Dietary Allowance), ultra-trace elements also benefit human health, including iodine, selenium, manganese, molybdenum, chromium, boron, and cobalt.

\section{The concentration of elements in honey}

By searching for publications on honey published in the last 10 years in PubMed and ScienceDirect database, 45 minerals are found in honey. (Table 2). 
Table 2. Minerals found in honey by countries as searched in PubMed and ScienceDirect database using "trace elements honey" as keywords [19-33].

\begin{tabular}{|c|c|}
\hline Location & Minerals found in honey \\
\hline Algeria [19] & $\begin{array}{c}\mathrm{K}, \mathrm{Mg}, \mathrm{Na}, \mathrm{Zn}, \mathrm{Fe}, \mathrm{Mn}, \mathrm{Cu}, \mathrm{Cr}, \mathrm{Ni}, \mathrm{Se}, \mathrm{As}, \mathrm{Pb}, \mathrm{Cd}, \mathrm{Sb}, \mathrm{Ti}, \mathrm{V}, \mathrm{Co}, \\
\mathrm{Hg}\end{array}$ \\
\hline Argentina [20] & $\mathrm{Br}, \mathrm{Ce}, \mathrm{Co}, \mathrm{Cr}, \mathrm{Cs}, \mathrm{Eu}, \mathrm{Fe}, \mathrm{La}, \mathrm{Rb}, \mathrm{Sb}, \mathrm{Sc}, \mathrm{Sm}, \mathrm{Th}, \mathrm{Zn}$ \\
\hline $\begin{array}{l}\text { Australian (Apis } \\
\text { mellifera) [21] }\end{array}$ & $\mathrm{Co}, \mathrm{Cu}, \mathrm{Cr}, \mathrm{Fe}, \mathrm{Mn}, \mathrm{Mo}, \mathrm{Zn}, \mathrm{Ca}, \mathrm{K}, \mathrm{Mg}, \mathrm{Na}, \mathrm{P}, \mathrm{B}, \mathrm{Sr}, \mathrm{Ni}$ \\
\hline Croatia $[22]$ & $\mathrm{As}, \mathrm{Cu}, \mathrm{Cd}, \mathrm{Pb}, \mathrm{Se}, \mathrm{Ca}, \mathrm{Fe}, \mathrm{K}, \mathrm{Mg}, \mathrm{Na}, \mathrm{Zn}, \mathrm{Hg}$ \\
\hline Egypt [23] & $\begin{array}{c}\text { Al, As, B, Ba, Be, Ca, Cd, Co, Cr, Cu, Fe, Hg, Mg, Mn, Mo, Ni, P, } \\
\text { Pb, Sb, Si, Ti, Tl, V, Zn }\end{array}$ \\
\hline Hungary [24] & $\mathrm{Al}, \mathrm{Ca}, \mathrm{Cu}, \mathrm{Fe}, \mathrm{K}, \mathrm{Mg}, \mathrm{Mn}, \mathrm{P}, \mathrm{S}, \mathrm{Zn}, \mathrm{As}, \mathrm{Cd}, \mathrm{Cr}, \mathrm{Mo}, \mathrm{Pb}, \mathrm{Se}$ \\
\hline Jordanian [25] & $\mathrm{Na}, \mathrm{K}, \mathrm{Mg}, \mathrm{Ca}, \mathrm{Fe}, \mathrm{Ni}, \mathrm{Cu}, \mathrm{Hg}, \mathrm{Pb}, \mathrm{Ag}$ \\
\hline Malaysia [26] & $\mathrm{Ca}, \mathrm{Mg}, \mathrm{Fe}, \mathrm{Zn}, \mathrm{Na}, \mathrm{K}, \mathrm{As}, \mathrm{Pb}, \mathrm{Cd}, \mathrm{Cu}, \mathrm{Co}$ \\
\hline New Zealand [27] & $\mathrm{K}, \mathrm{P}, \mathrm{Ca}, \mathrm{Cd}, \mathrm{Pb}, \mathrm{Zn}$ \\
\hline NS [28] & $\begin{array}{c}\mathrm{Ag}, \mathrm{Al}, \mathrm{As}, \mathrm{B}, \mathrm{Ba}, \mathrm{Be}, \mathrm{Ca}, \mathrm{Cd}, \mathrm{Co}, \mathrm{Cr}, \mathrm{Cu}, \mathrm{Fe}, \mathrm{Hg}, \mathrm{Mg}, \mathrm{Mn}, \mathrm{Mo}, \mathrm{Ni}, \\
\mathrm{Pb}, \mathrm{Sb}, \mathrm{Se}, \mathrm{Si}, \mathrm{Ti}, \mathrm{Tl}, \mathrm{V}, \mathrm{Zn}\end{array}$ \\
\hline NS [29] & $\mathrm{K}, \mathrm{Ca}, \mathrm{Mg}, \mathrm{Na}, \mathrm{Fe}, \mathrm{Li}, \mathrm{Zn}$ \\
\hline Portugal [30] & $\begin{array}{c}\mathrm{Ag}, \mathrm{As}, \mathrm{Br}, \mathrm{Ca}, \mathrm{Cl}, \mathrm{Cs}, \mathrm{Cu}, \mathrm{Fe}, \mathrm{K}, \mathrm{La}, \mathrm{Mg}, \mathrm{Mn}, \mathrm{Na}, \mathrm{Rb}, \mathrm{Sb}, \mathrm{Sc}, \mathrm{U}, \mathrm{V} \\
\text { and } \mathrm{Zn}\end{array}$ \\
\hline Poland [31] & $\mathrm{Al}, \mathrm{B}, \mathrm{Ba}, \mathrm{Ca}, \mathrm{Cd}, \mathrm{Cr}, \mathrm{Cu}, \mathrm{K}, \mathrm{Mg}, \mathrm{Mn}, \mathrm{Na}, \mathrm{Ni}, \mathrm{Pb}, \mathrm{Sr}, \mathrm{Zn}$ \\
\hline Turkey [32] & $\begin{array}{c}\mathrm{Al}, \mathrm{Ba}, \mathrm{Ca}, \mathrm{Cd}, \mathrm{Cr}, \mathrm{Co}, \mathrm{Fe}, \mathrm{Cu}, \mathrm{K}, \mathrm{Mg}, \mathrm{Mn}, \mathrm{Ni}, \mathrm{Na}, \mathrm{Pb}, \mathrm{Sr}, \mathrm{Ag}, \mathrm{Bi}, \\
\text { Ga, In, Li, Ti, Zn }\end{array}$ \\
\hline Turkey [33] & $\mathrm{K}, \mathrm{Na}, \mathrm{Ca}, \mathrm{Fe}, \mathrm{Zn}, \mathrm{Cd}, \mathrm{Cu}, \mathrm{Mn}, \mathrm{Pb}, \mathrm{Ni}, \mathrm{Cr}, \mathrm{Al}, \mathrm{Se}$ \\
\hline
\end{tabular}

Note: NS=Not state.

Trace elements found in honey determine the level of honey quality. Based on the study by Bogdanove et al. [34], minerals content in honey vary with the estimated range of $0.04 \%$ (for pale yellowish honey) to $0.20 \%$ (for dark-colored honey). The trace elements content in honey is used as the standards to ensure that the honey is safe to be consumed and absorbed by the human body. The ash content is a parameter used to determine the number of minerals present in honey. Referring to the Codex Alimentarius (International Food Standard), the ash content in honey should not be more than $0.6 \%$. The major mineral content in honey is commonly obtained from soil and nectar-producing plants, such as fruit trees and flowering plants. The content of minerals and heavy metals is also influenced by the environment, geographic area, and anthropogenic factors $[35,36]$.

Mineral elements, such as $\mathrm{K}, \mathrm{Na}, \mathrm{Ca}, \mathrm{Fe}, \mathrm{Zn}, \mathrm{Cd}, \mathrm{Cu}, \mathrm{Mn}, \mathrm{Pb}, \mathrm{Ni}, \mathrm{Cr}, \mathrm{Al}$, and Se may be present in unifloral honey and polyfloral honey, and it has become the objective of the researchers to study the level of these elements. In order to determine their concentration in honey samples, instruments like the Plasma Coupling Induced Mass Spectrometer (ICP-MS) [30] or the Plasma Coupling Induced-Optical Emission Spectrometer (ICP-OES) will be used to analyzed them. The most abundant elements found in bee honey and kelulut honey were $\mathrm{K}, \mathrm{Na}, \mathrm{Ca}$ and $\mathrm{Mg}$ [37 - 40]. Table 3 shows the concentrations of the elements analyzed through laboratory studies in different countries. 
Table 3. Elements and their concentration in honey by location based on four different studies [34, $38,40,41]$.

\begin{tabular}{|c|c|c|}
\hline Elements & Concentration & Location \\
\hline \multirow{2}{*}{ Potassium (K) } & $880.73 \mathrm{mg} / \mathrm{kg}$ & Malaysia \\
\hline & $761.22 \mathrm{mg} / \mathrm{kg}$ & Malaysia \\
\hline \multirow{3}{*}{ Iron $(\mathrm{Fe})$} & $35.6 \mu \mathrm{g} / \mathrm{l}$ & Switzerland \\
\hline & $10.26 \mathrm{mg} / \mathrm{kg}$ & Thailand \\
\hline & $781 \mathrm{mg} / \mathrm{kg}$ & Malaysia \\
\hline Sodium $(\mathrm{Na})$ & $589.46 \mathrm{mg} / \mathrm{kg}$ & Malaysia \\
\hline \multirow{2}{*}{ Calcium (Ca) } & $292.67 \mathrm{mg} / \mathrm{kg}$ & Malaysia \\
\hline & $205.98 \mathrm{mg} / \mathrm{kg}$ & Malaysia \\
\hline Magnesium (Mg) & $41.06 \mathrm{mg} / \mathrm{kg}$ & Malaysia \\
\hline \multirow{2}{*}{ Chromium (Cr) } & $36.2 \mu \mathrm{g} / 1$ & Switzerland \\
\hline & $0.489 \mathrm{mg} / \mathrm{kg}$ & Thailand \\
\hline \multirow{4}{*}{ Zinc (Zn) } & $54.5 \mu \mathrm{g} / 1$ & Switzerland \\
\hline & $4.37 \mathrm{mg} / \mathrm{kg}$ & Malaysia \\
\hline & $9.461 \mathrm{mg} / \mathrm{kg}$ & Thailand \\
\hline & $3.03 \mathrm{mg} / \mathrm{kg}$ & Malaysia \\
\hline \multirow{2}{*}{ Mangan (Mn) } & $123.0 \mu \mathrm{g} / \mathrm{l}$ & Switzerland \\
\hline & $8.16 \mathrm{mg} / \mathrm{kg}$ & Thailand \\
\hline \multirow{2}{*}{ Copper $(\mathrm{Cu})$} & $88.8 \mu \mathrm{g} / 1$ & Switzerland \\
\hline & $2.482 \mathrm{mg} / \mathrm{kg}$ & Thailand \\
\hline Lead $(\mathrm{Pb})$ & $28.5 \mu \mathrm{g} / 1$ & Switzerland \\
\hline Nickel (Ni) & $27.3 \mu \mathrm{g} / 1$ & Switzerland \\
\hline Cadmium (Cd) & $23.7 \mu \mathrm{g} / 1$ & Switzerland \\
\hline
\end{tabular}

\section{Sources of heavy metal pollution}

Heavy metals and metalloids in the soil can occur naturally or by pollution activities. Anthropogenic pollutions, such as industrial and agricultural wastes may produce lethal and sublethal toxic effects on bees [42]. Consequently, bees can act as bioindicator or biosensor agents that can detect polluted area due to the presence of high heavy metals concentration (Figure 2). 


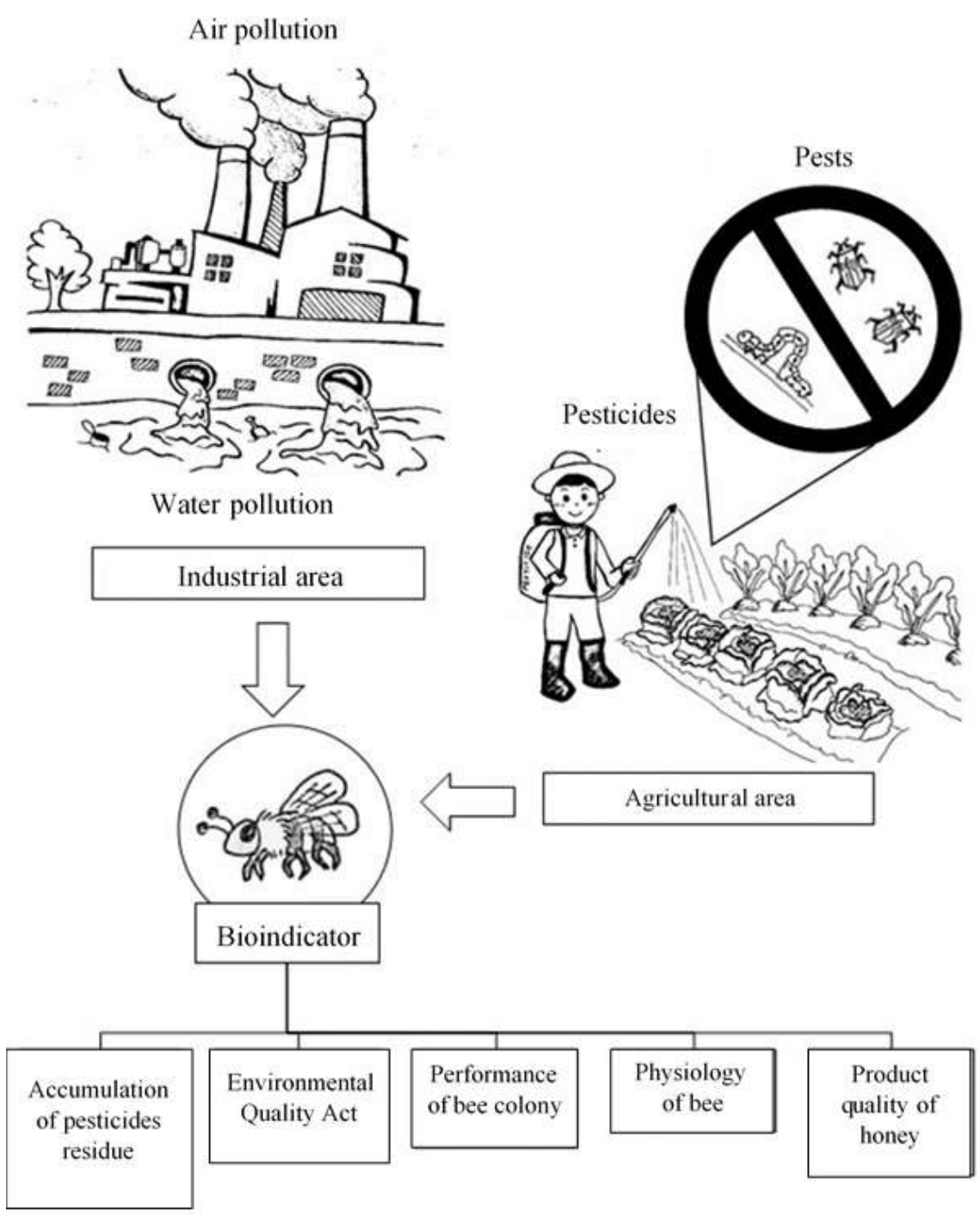

Figure 2. Heavy metals discharged from industrial and agricultural wastes are highly toxic, polluting the environment when they accumulate in high concentration. Bees act as bioindicators through the abnormalities in their performance colony, physiology changes and the quality honey products.

The industries that can lead to heavy metals pollution are the mining and ore processing industry, metallurgy and plating, chemicals industry, dye and pigment industry and petroleum refinery [43]. Besides that, heavy metals also occur due to soil erosion, industrial effluent discharge, sewage disposal and pesticide usage in agriculture either through the air, water and soil [44]. The heavy metals released such as $\mathrm{As}, \mathrm{Cd}, \mathrm{Hg}, \mathrm{Pb}, \mathrm{Cr}$, $\mathrm{Cu}, \mathrm{Ni}$ and $\mathrm{Zn}$ can jeopardize human health as well as animal habitats [45]. According to Kováčik et al. [46], there are carcinogenic and cytotoxic elements like $\mathrm{Pb}, \mathrm{Cd}, \mathrm{Ni}$ and $\mathrm{Cr}$ found in honey at high concentrations, especially those located close to the industrial and urban areas.

\subsection{The exposure of agrochemical to bees}

Agrochemical is a chemical used in agriculture, such as pesticides and fertilizers. Pesticide is used to control the growth of pests while fertilizer supplies nutrients to plants. In general, pesticide is made from chemical compounds used to kill crops-damaging pests, like insects, rodents, and unwanted plants (weeds). However, 
excessive and uncontrolled use of these pesticides will negatively impact non-target organisms and biodiversity. There are various groups of pesticides available in the market, such acaricides, organic acids, insecticides, fungicides, herbicides and bactericides [47]. Each of these pesticides is meant to be effective against specific pests.

Pesticides can be produced from natural or synthetic compounds. Organochlorine, carbamate, organophosphates, pyrethroids and neonicotinoids are types of pesticides widely chosen and used by farmers to protect their crops. Pesticides are volatile and easy to dissolve in water, thus leaching into water sources like rivers, ponds or oceans [48]. If the pesticide has a high solubility in water, it will remain soluble in water and may end up in a nearby stream due to runoff. Other than that, the chemicals released from the pesticides will be absorbed into the soil too. Consequently, it will pollute surface water and groundwater (by leaching process), and impact soil fertility which adversely affects the beneficial soil microorganisms. Soil microorganisms are important to plants because they help in the process of turning the atmospheric nitrogen into nitrate [49].

The effects of using pesticides depend on the types of pesticides used. For example, neonicotinoids can contaminate soil and waterways and attack nontarget crops. The effects may be prolonged because the lifespan of neonicotinoids in the soil can exceed 1000 days, and it potentially accumulates in the soil if used repeatedly [50]. According to Botías et al. [51], the higher residue of neonicotinoid is found in pollen and nectar of wild plants growing around farm areas than that found in farm crops.

Within 10 years (between 2009 and 2019), based on the literature search within ScienceDirect database, the pesticide and toxic elements found in honey across the country showed an increasing trend (Figure 3). Research showing honey contaminated by pesticides was relatively high with 1796 publications while 74 publications showed toxic elements in honey. However, this topic will keep increasing year after year due to urbanization and development in many countries, which eventually requires the production of agricultural products quickly to support their residents. Thus, they will need chemicals to help speed up the rate of production in agriculture, like fertilizers and pesticides.

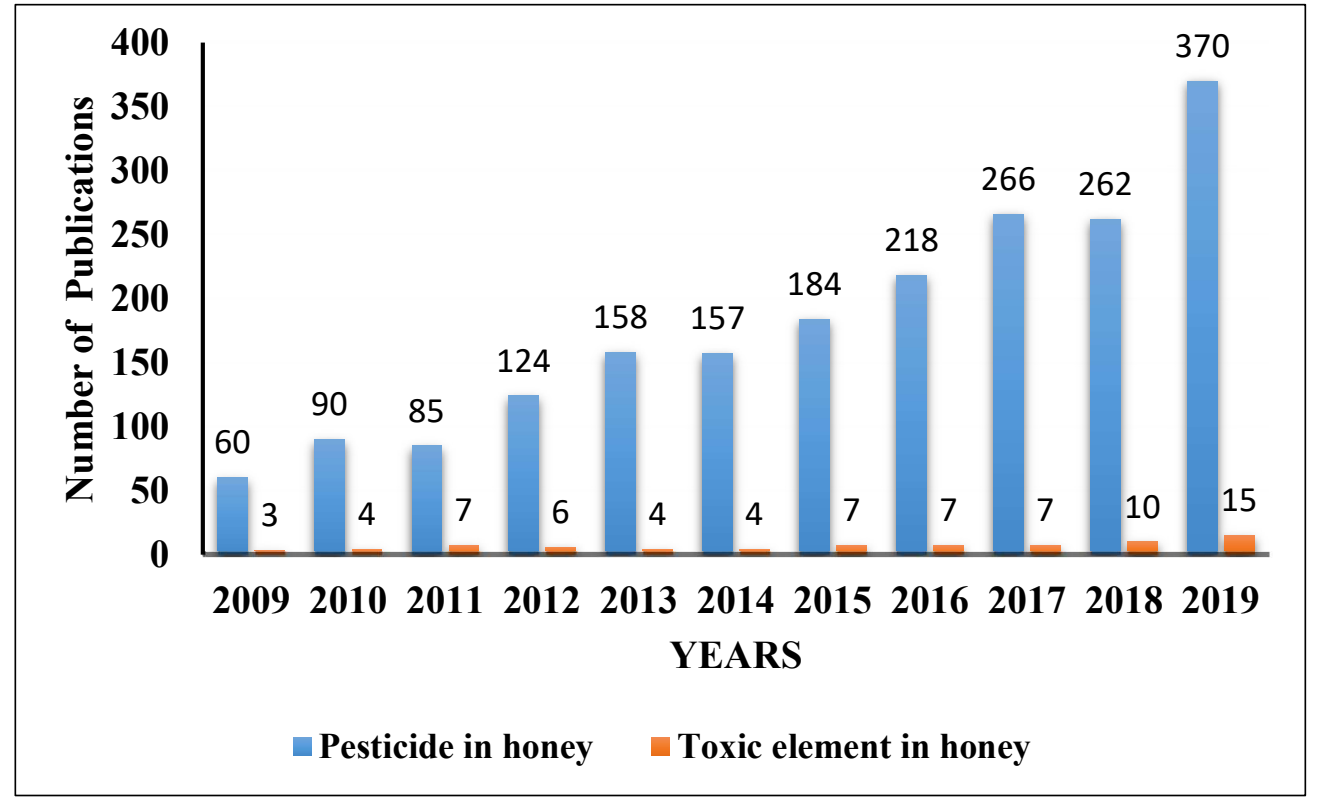

Figure 3. Number of publications in a period of 10 years. Information was taken from the ScienceDirect database using two research queries, "Pesticide in Honey" and "Toxic elements in honey" (Search conducted in June 2020).

Some pesticides are carcinogenic, potentially causing chromosomal abrasions [52], and the pesticide residue can harm humans, leading to genetic mutations and cellular defects [47]. 
Table 4. List of types of pesticides that have been identified in honey and pollen products from several locations [53-57].

\begin{tabular}{|c|c|c|}
\hline Honey & Location & Type of pesticide \\
\hline Honey bee & Belgium & $\begin{array}{l}\text { Fungicide, pyrimethanil } \\
\text { and insecticide detected. [53] }\end{array}$ \\
\hline Honey bee & Ghana & $\begin{array}{l}\text { Organophosphorus and pyre- } \\
\text { throids detected in very low } \\
\text { concentration. [54] }\end{array}$ \\
\hline Honey bee & Hawaii Island & $\begin{array}{l}118 \text { ppb glyphosate in } 0.5 \mathrm{~g} \\
\text { honey [55] }\end{array}$ \\
\hline Honey bee & Mexico Southern & $\begin{array}{c}\text { Organochlorine has been iden- } \\
\text { tified in concentration range } \\
\text { between } 0.51 \text { to } 370.56 \mathrm{ug} / \mathrm{kg} \\
\text { honey. [56] }\end{array}$ \\
\hline Honey bee (pollen) & Poland & $\begin{array}{l}\text { Fungicide and prothioconazole } \\
\text { were detected where prothio- } \\
\text { conazale showed high concen- } \\
\text { tration with } 356 \mu \mathrm{g} \mathrm{kg}^{-1} \text {. [57] }\end{array}$ \\
\hline
\end{tabular}

\section{The interaction of bees with environment}

Bees are important in the agriculture as the most effective pollinating agents. Pollination is the primary key to global biodiversity, providing important ecosystem services to wild crops and plants [58]. Bees are indirectly involved in producing seeds and fruits, and increasing the success rate of reproduction of plants around them. Bees have a high chance of being exposed to heavy metals via water sources, and nectar and pollens accumulated with heavy metals [42].

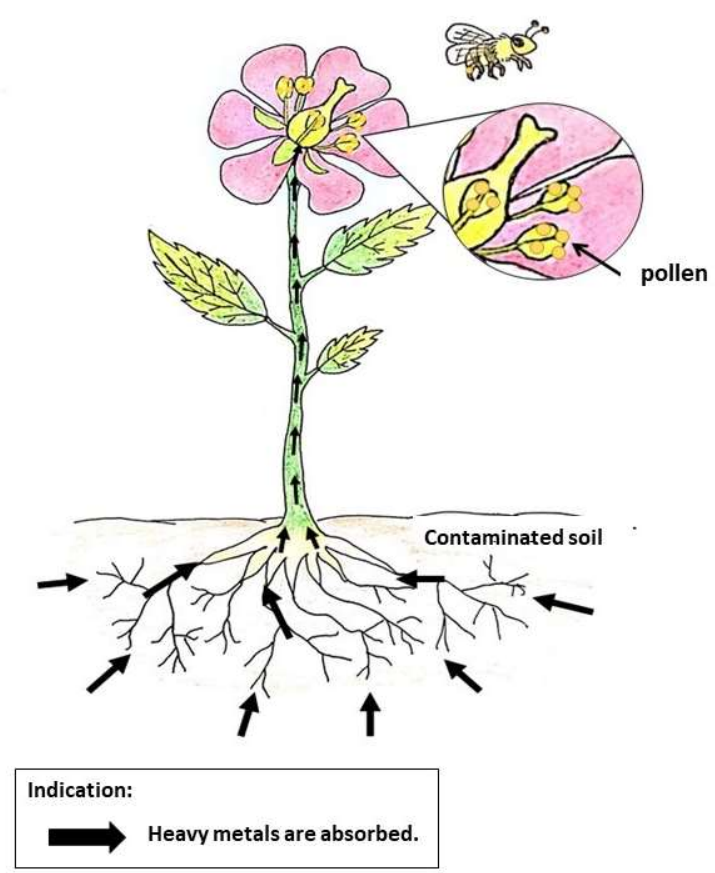

Figure 4. Heavy metals will be actively absorbed by root hairs in the form of dissolved ions from contaminated soil and then transported along with water through the vascular system to the rest of the plant cells. The pollen is easily contaminated by exposure to air pollution that contains heavy metal particles in the air. 
The number of heavy metals contained in a plant will keep increasing as the amount of heavy metals present in the soil increases. Meanwhile, air pollution also pollutes pollen by causing heavy metals like lead present in the air to stick to the pollen. Bees alighting on flowers will collect both contaminated pollen and nectar, and carry them to the hive (Figure 4). However, different plant species have different rates of assimilating heavy metals. Previous studies found that the presence and the accumulation of heavy metals such as $\mathrm{Cr}, \mathrm{Cd}, \mathrm{Pb}$ and $\mathrm{Ni}$ in the beehives depend on atmospheric particulate matter, and they caused the death of bee colonies [59,60].

The pesticide residues in pollen, and nectar are also carried by bees to their hive, and these residues will remain in the bee bread and honey for some period before being fed to the larvae and queen [61]. Based on the studies that have been conducted in the U.S, there was pesticide residue present in honey samples collected from 23 states where they used honeybees as a pollinator agent [62]. Moreover, previous research studies have shown that honey, propolis and wax in bees' colonies worldwide contain various toxins, including pesticides, herbicides, and some heavy metals [63].

\section{The effect of heavy metals towards bees}

Bees can potentially detect some chemical toxins through the receptors on their antenna and proboscis. They also have the ability to recognize harmful substances by the malaise reaction that arises after ingestion, and this can be attributed to the taste of the substance. Then, the bees will avoid it in the future [64]. However, not all toxic compounds can give a malaise effect to bees. It depends on how many bees that have been exposed to them. Moreover, heavy metals like selenium, a toxic metalloid, at high concentrations cannot be detected through the antenna and proboscis of the bees [65].

A high concentration of heavy metals will directly interfere with the bees' nerve pathways. Damaging in bee brains' affect their cognitive capacity lead them fail to navigate properly. The worker bees which cooperate in food collection needs to have a high cognitive capacity in order to allocate the radius of the nectar source, determine the location of high-quality feeding sites, and efficiently navigate back to the brood nest for nectar and pollen reservation [66].

\subsection{The effect of pesticide towards bees}

Neonicotinoid insecticides, such as imidacloprid, thiacloprid, and guadipyr are popular pesticides used by farmers around the world. These pesticides act systematically and move through plant tissues, and are highly toxic to most arthropod insects. These pesticides affect bee's behaviour, making them abnormal. Previous research studies prove that imidacloprid leads to sublethal damage like cellular damage including severe lesions in the midgut wall $[67,68]$.

Imidacloprid is a systemic insecticide that acts as a neurotoxin to insects, disrupting the central nervous system. It is absorbed by plants, spreading to all tissues including pollen and nectar through the vascular system and indirectly transmitting to the hive during pollen and nectar delivery [68,69]. Imidacloprid negatively affects the development of bee brain as detected through the immunolabelling of the synaptic units of the petals of the corpora pedunculate [67], and increases the mortality of bees [69].

\subsection{The effect on bee product}

Pollution of heavy metals and pesticides affects bees and bee colonies. It affects the quality of bees' productivity in the hive, such as the production of honey, propolis, beeswax, bee pollen and bee bread. The presence of heavy metals, like $\mathrm{Pb}, \mathrm{Cd}, \mathrm{Cu}, \mathrm{Zn}$, $\mathrm{Mn}, \mathrm{Hg}$, As and insecticides, like organochlorine, organophosphates, pyhrethrins and pyrethroids in honey samples have been identified by several studies [70 - 72]. Authors [73-75], detected the presence of heavy metals, such as $\mathrm{Cd}, \mathrm{Pb}, \mathrm{Fe}, \mathrm{Mg}, \mathrm{Zn}$ and $\mathrm{As}$ in samples of propolis, beeswax and bee pollen. Nascimento et al. [76] also detected some 
heavy metals present in the pollen stored by the stingless bees that live near mining activities.

Furthermore, there is poison honey produced by bees derived from poisonous plants, resulting in toxicity towards humans. For example, honey produced from the leaves of plants belonging to the family Ericaceae, such as Rhododendron ponticum and Andromeda contains alkaloids and grayanotoxins that can cause paralysis in human limbs and can lead to death [77]. This occurrence requires more scientific research to prevent these toxic bee honey sales by beekeepers.

\section{Conclusion}

Bee colonies and bee products are critical as monitoring agents to determine the quality of the environment and thus, identify the environment contaminated with heavy metals and pesticides. However, more detailed studies are needed to maintain the quality of bee products so that the nutrients contained in the products are not affected and a danger to consumers. In addition, a similar study should be developed for stingless bee or kelulut species because kelulut honey is gaining attention not only in Malaysia, but also around the world. Consequently, areas that may be potentially exposed to contaminants should be identified and monitored. Through this monitoring method, the quality of honey-based products will be guaranteed, as well as maintaining the title of Superfood Malaysia, thus helping entrepreneurs generate income and promoting environmental sustainability.

Acknowledgments: The author would like to thank Universiti Malaysia Sabah for providing the University Research Fund (UMSGREAT GRANT GUG500-1/2020).

\section{References}

1. Eteraf-Oskouei, T.;Najafi. Traditional and Modern Uses of Natural Honey in Human Diseases: A Review. Iran J Basic Med Sci. 2013. 16(6):731-742. PMID: 23997898; PMCID: PMC3758027.

2. Samarghandian, S., Farkhondeh, T., \& Samini, F. (2017. Honey and Health: A Review of Recent Clinical Research. Pharmacognosy research, 9(2). 2017. 121-127. https://doi.org/10.4103/0974-8490.204647

3. Ahmed, S., Sulaiman, S. A., Baig, A. A., Ibrahim, M., Liaqat, S., and Fatima, S., Honey as a potential natural antioxidant medicine: an insight into its molecular mechanisms of action Oxid. Med. Cell Longev., 2018 (2018), p. 8367846

4. Jacoby, D. B., and Choi, A. M,. Influenza virus induces expression of antioxidant genes in human epithelial cells. Free Radic. Biol. Med., 1994. 16 (6). pp. 821-824

5. Watanabe, K., Rahmasari, R., Matsunaga, A., Haruyama, T., and Kobayashi, N. Anti-influenza viral effects of honey in vitro: potent high activity of manuka honey. Arch. Med. Res. 2014. 45(5):359-65. doi: 10.1016/j.arcmed.2014.05.006

6. Charyasriwong, S., Haruyama, T., and Kobayashi, N. In vitro evaluation of the antiviral activity of methylglyoxal against influenza B virus infection. Drug Discov. Ther., 2016. 10 (4) : 201-210

7. Hossain, K. S., Hossain, M. G., Moni, A., Rahman, M. M., Rahman, U. H., Alam, M., Kundu, S., Rahman, M. M., Hannan, M. A., Uddin, M. J. Prospects of honey in fighting against COVID-19: pharmacological insights and therapeutic promises. Heliyon. 2020. 6 (2020) e05798. https://doi.org/10.1016/j.heliyon.2020.e05798

8. Mustafa, M. Z., Shamsuddin, S. H., Sulaiman, S. A., and Abdullah, J. M., Anti-inflammatory properties of stingless bee honey may reduce the severity of pulmonary manifestation in COVID-19 infections. Malays J Med Sci. 2020. 27 (2):165-169 doi: 10.21315/mjms2020.27.2.17

9. Kattappagari, K. K.; Ravi Teja, C. S.; Kommalapati, R. K.; Poosarla, C.; Gontu, S. R.; Reddy, B. V. Role of antioxidant in facilitating the body functions: A Review. Journal Of Orofacial Science. 2015. 7 (7): 1-5. DOI: 10.4103/0975-8844.169745

10. Cornara, L.; Biagi, M.; Xiao, J.; Burlando, B. Therapeutic Properties of Bioactive Compounds from Different Honeybee Products. Front. Pharmaco. 2017. https://doi.org/10.3389/fphar.2017.00412

11. Ediriweera, E. R. H. S. S.; Premarathna, N. Y. S. Medicinal and cosmetic uses of Bee's Honey-A review. An International Quaterly Journal Of Research in Ayuveda. 2012. 33(2):178-182. doi: 10.4103/0974-8520.105233

12. Wan Ismail, W. I. A Review On Beekeeping in Malaysia: History, Importance and Future Directions. Journal of Sustainability Science and Management. 2016. 11(2):70-80. ISSN:1823-8556

13. Patel, V., Pauli, N., Biggs, E., Barbour, L., and Boruff, B. 2020. Why bees are critical for achieving sustainable development. AMBIO A Journal of the Human Environment. 50 (1). DOI:10.1007/s13280-020-01333-9

14. Nielsen, F. H. 1999. Ultratrace minerals. In Modern Nutrition in health and disease. $9^{\text {th }}$ edn (eds Shils ME, Olsen JA, Shike M, Ross AC). Pp:283-303. Baltimore, MD: Williams and Wilkins.

15. Belitz, H.; Grosch, W.; Schieberle, P. 2009. Food Chemistry. $4^{\text {th }}$ revised and extended ed. Berlin, London: Springer, 1070 pages. 
16. Uriu-Adams, J.; Keen, C. L. Copper, oxidative stress and human health. Molecular Aspects of Medicine. 2005. 26(4-5):268-298. doi: 10.1016/j.mam.2005.07.015.

17. Hordyjewska, A.; Popiolek, L.; Kocot, J. The many "faces" of copper in medicine and treatment. Biometals: an international journal on the role of metals ions in biology, biochemistry and medicine. 2014. 27(4):611-621. https://doi.org/10.1007/s10534-014-9736-5

18. Puing, S.; Thiele, D. J. Moleculer Mechanisms of Copper Uptake and Distribution. Curr Opin Chem Biol. 2002. 6(2):171-180. doi: 10.1016/s1367-5931(02)00298-3.

19. Bella, G.D.; Licata, P.; Potortì, A.G.; Crupi ,R.; Nava, V.; Qada, B.; Rando, R.; Bartolomeo, G.; Dugo, G.; Turco, V.L. Mineral content and physico-chemical parameters of honey from North regions of Algeria. Nat Prod Res. 2020. 9:1-8. doi: 10.1080/14786419.2020.1791110. PMID: 32643412.

20. Pellerano, R. G.; Uñates, M. A.; Cantarelli, M. A.; Camiña, J. M.; Marchevsky, E. J. Analysis of trace elements in multifloral Argentine honeys and their classification according to provenance. Food Chemistry. 2012. 134(1):578-582, ISSN 0308-8146, https://doi.org/10.1016/j.foodchem.2012.02.125

21. Hungerford, N.L.; Tinggi, U.;Tan, B.L.L.; Farrell, M.; Fletcher, M.T. Mineral and Trace Element Analysis of Australian/Queensland Apis mellifera Honey. Int J Environ Res Public Health. 2020. 17(17):6304. doi: 10.3390/ijerph17176304. PMID: 32872537; PMCID: PMC7503739

22. Bilandžić, N.; Gačić, M.; Đokić, M.; Sedak, M.; Šipušić, D. I.; Končurat, A.; Gajger, T. Major and trace elements levels in multifloral and unifloral honeys in Croatia, Journal of Food Composition and Analysis, 2014. 33(2):132-138. ISSN 0889-1575, https://doi.org/10.1016/j.jfca.2013.12.002.

23. Karabagias, I.K.; Louppis, A.P.; Kontakos, S.; Drouza, C.; Papastephanou, C. Characterization and Botanical Differentiation of Monofloral and Multifloral Honeys Produced in Cyprus, Greece, and Egypt Using Physicochemical Parameter Analysis and Mineral Content in Conjunction with Supervised Statistical Techniques. J Anal Methods Chem. 2018. 2018:7698251. doi: 10.1155/2018/7698251. PMID: 29967713; PMCID: PMC6008861.

24. Czipa, N.; Andrási, D.; Kovács, B. Determination of essential and toxic elements in Hungarian honeys, Food Chemistry. 2015. 175: 536-542. ISSN 0308-8146, https://doi.org/10.1016/j.foodchem.2014.12.018.

25. Abdelghani, J.I.; Abu-Nameh, E.S.; Zaitoun, S.T.; Abu-Zir, A.I. Preliminary study of the influence of mineral content on quality parameters of Jordanian-origin honey collected from different geographical regions. J Food Sci Technol. 2019. 56(11):4817-4825. doi: 10.1007/s13197-019-03942-z. PMID: 31741506; PMCID: PMC6828924.

26. Moniruzzaman, M.; Chowdhury, M. A. Z.; Rahman, M. A.; Sulaiman, S. A.; Gan, S. H. Determination of Mineral, trace element and pesticide levels in honey samples originating from different regions of Malaysia compared to manuka honey. BioMed Research International. 2014. vol. 2014, Article ID 359890, 10 pages, 2014. https://doi.org/10.1155/2014/359890

27. Vanhanen, L. P.; Emmertz, A.P.; Savage, G. Mineral analysis of mono-floral New Zealand honey. Food Chemistry. 2011. 128(1):236-240. ISSN 0308-8146. https://doi.org/10.1016/j.foodchem.2011.02.064.

28. Louppis, A.P.; Karabagias, I.K.; Papastephanou, C.; Badeka, A. Two-Way Characterization of Beekeepers' Honey According to Botanical Origin on the Basis of Mineral Content Analysis Using ICP-OES Implemented with Multiple Chemometric Tools. Foods. 2019. 8(6):210. doi: 10.3390/foods8060210. PMID: 31207956; PMCID: PMC6617083.

29. Kadri, S.M.; Zaluski, R.; Orsi, R.O. Nutritional and mineral contents of honey extracted by centrifugation and pressed processes. Food Chem. 2017. 218:237-241. doi: 10.1016/j.foodchem.2016.09.071. PMID: 27719904.

30. Almeida-Silva, M.; Canha, N.; Galinha, C.; Dung, H. M.; Freitas, M. C.; Sitoe, T. Trace elements in wild and orchard honeys. Applied Radiation and Isotopes. 2011. 69(11):1592-1595, ISSN 0969-8043, https://doi.org/10.1016/j.apradiso.2011.01.013.

31. Chudzinska, M.; Baralkiewicz, D. Application of ICP-MS method of determination of 15 elements in honey with chemometric approach for the verification of their authenticity. Food and Chemical Toxicology. 2011. 49(11):2741-2749. ISSN 0278-6915. https://doi.org/10.1016/j.fct.2011.08.014

32. Tutun, H.; Kahraman, H.A.; Aluc, Y.; Avci, T.; Ekici, H. Investigation of some metals in honey samples from West Mediterranean region of Turkey. Vet Res Forum. 2019. 10(3):181-186. doi: 10.30466/vrf.2019.96726.2312. PMID: 31737225; PMCID: PMC6828168.

33. Kılıç Altun, S.; Dinç, H.; Paksoy, N.; Temamoğulları, F.K.; Savrunlu, M. Analyses of Mineral Content and Heavy Metal of Honey Samples from South and East Region of Turkey by Using ICP-MS. Int J Anal Chem. 2017. 2017:6391454. doi: 10.1155/2017/6391454.. PMID: 28584526; PMCID: PMC5444030.

34. Bogdanov, S.; Haldimann, M.; Luginbuhl, W.; Gallmann, P. Minerals in honey: environmental, geographical and botanical aspects. Journal of Apicultural Research and Bee World. 2007. 46(6):269-275. https://doi.org/10.1080/00218839.2007.11101407

35. Vincevica-Gaile, Z. 2010. Micro- and trace elements in honey. Universitu of Latvia, Riga (Latvia). Faculty of Geograpgh and Earth Sciences. 25340. Pp 54-66. ISSN: 1407-4427

36. Solayman, M.; Islam, M. A.; Paul, S.; Ali, Y.; Khalil, M. I.; Alam, N.; Gan, S. H. Physicochemical Properties, Minerals, Trace Elements, and Heavy Metals in Honey of Different Origins: A Comprehensive Review. Comprehensive Review in Food Science and Food Safety. 2015. 15(1). https://doi.org/10.1111/1541-4337.12182

37. Altun, S. K.; Dinç, H.; Paksoy, N.; Temamoğulları, F. K.; Savrunlu, M. Analyses of Mineral Content and Heavy Metal of Honey Samples from South and East Region of Turkey by Using ICP-MS. Interntional Journal of Analytical Chemistry. 2017. 2017. Article ID 6391454. https://doi.org/10.1155/2017/6391454 
38. Abu Bakar, M. K.; Sanusi, S. B.; Abu Bakar, F. I.; Cong, O. J.; Mian, Z. Short Communication Physicochemical and Antioxidant Potential of Raw Unprocessed Honey From Malaysia Stingless Bees. Pak. J. Nutr., 2017. 16(11):888-894, 2017. DOI: 10.3923/pjn.2017.888.894

39. Wetwitayaklung, P.; Wangwattana, B.; Narakornwit, W. Determination of trace-elements and toxic heavy minerals in Thai Longan, litchi and Siam weed honeys using ICP-MS. International Food Research Journal. 2017. 25(4):1464-14773.

40. Cheng, M. Z. S. Z.; Ismail, M.; Chan, K. W.; Ooi, D. J.; Ismail, N.; Zawawi, N.; Esa, N. K. Comparison of Sugar Content, Mineral Elements and Antioxidant Properties of Heterotrigona Itama Honey from Suburban and Forest in Malaysia. Malaysia Journal of Medicine and Health Science. 2019. 15(SP1): 104-112. eISSN 2636-9346

41. Chuleeporn, S.; Anothai, T.; Bundit, T. Micro Mineral Contents in Thai Honey. International Journal of Applied Engineering Research. 2018. 6(13):4153-4156. ISSN 0973-4562

42. Feldhaar, H.; Otti, O. Pollutants and Their Interaction with Diseases of Social Hymenoptera. Insect. 2020. $11(3)$ : 153. https://doi.org/10.3390/insects11030153

43. Nagajyoti, P. C.; Lee, K. D.; Sreenkanth, T.V. M. Heavy metals, occurrence and toxicity for plants. A Review. Environmental Chemistry Letters. 2010. 8:199-216. https://doi.org/10.1007/s10311-010-0297-8

44. Morais, S.; Costa, F. G.; Pereira, M. L. Heavy metals and human health. In: Oosthuizen J, editor. Environment health-emerging issues and practice. 2012. Pp. 227-246

45. Lambert, M.; Leven, B. A.; Green, R. M. 2000. New Methods of Cleaning Up Heavy Metal in Soil and Water; Environmental science and technology brief for citizens; Manhattan, KS: Kansas State University; 2000.

46. Kováčik, J.; Biba, J. G. O.; Hedbavny, J. Content of metals and metabolites in honey originated from the vicinity of industrial town Košice (estern Slovakia). Environ Sci Pollut Res. 2016. 23:4531-4540. https://doi.org/10.1007/s11356-015-5627-8

47. Al-Waili, N.; Salom, K.; Al-Ghamdi, A.; Ansari, M. J. Antibiotic, Pesticide and Microbial Contamination of Honey: Human Health Hazard. The Scientific World Journal. 2012. 2012. https://doi.org/10.1100/2012/930849

48. Institute of Agriculture and Natural Resources. Chemical \& Physical Characteristics of Pesticides. Retrieved on 14/04/2020 from https://water.unl.edu/article/crop-production/chemical-physical-characteristics-pesticides

49. Aktar, M. W.; Sengupta, D.; Chowdhury, A. Impact of pesticides use in agriculture: their benefits and hazard. Interdisciplinary Toxicology. 2009. 2(1), 1-12. doi: 10.2478/v10102-009-0001-7.

50. Bonmatin, J-M.; Giorio, C.; Girolami, V.; Goulson, D.; Kreutzweiser, D. P.; Krupke, C.; Liess, M.; Long, E.; Marzaro, M.; Mitchell, E. A. D.; Noome, D. A.; Simon-Delson, N.; Tapparo, A. Environmental Fate and Exposure; Neonicotinoids and Fipronil. Envrion Sci Pollut Res Int. 2015. 22(1):35-67. https://doi.org/10.1007/s11356-014-3332-7

51. Botías, C.; David, A.; Horwood, J.; Abdul-Sada, A.; Nicholls, E.; Hill, E.; Goulson, D. Neonicotinoid Residues in Wildflowers, a Potential Route of Chronic Exposure for Bees. Environmental Science E Technology. 2015. 49(21):12731-12740. https://doi.org/10.1021/acs.est.5b03459

52. Tabi, J. A.; Adjaloo, M. K.; Borquaye, L. S. Pesticide Residues in Honey from the Major Honey Producing Forest Belts in Ghana. Journal of Environment and Public Health. 2017. 2017. ID:7957431

53. Simon-Delson, N.; Martin, G. S.; Bruneau, E.; Delcourt, C.; Hautier, L. The challenge of predicting pesticide exposure of honey bees at landscape level. Scientific Reports. 2017. 7(1):3801. DOI:10.1038/s41598-017-03467-5

54. Darko, G.; Tabi., J. A.; Adjaloo, M. K.; Borquaye, L. S. Pesticide Residue in Honey from the Major Honey Producing Forest Belts in Ghana. Journal of Environmental and Public Health. 2017. Vol. 2017. https://doi.org/10.1155/2017/7957431

55. Berg, C. J.; King, H. P.; Delenstarr, G.; Kumar, R.; Rubio, F.; Glaze, T. Glyphosate residue concentrations in honey attributed through geospatial analysis to proximity of large-scale agriculture and transfer off-site by bees. PLoS ONE. 2018. 13(7):e0198876. https://doi.org/10.1371/journal.pone.0198876

56. Ruiz-Toledo, J.; Vandame, R.; Castro-Chan, R.; Penilla-Navarro, R. P.; Gómez, J.; Sánchez, D. Organochlorine Pesticides in Honey and Pollen Samples from Managed Colonies of the Honey Bee Apis mellifera Linnaeus and the Stingless Bee Scaptotrigona Mexicana Guérin from Southern, Mexico. Insects. 2018. 9(2):54. doi: 10.3390/insects9020054.

57. Roszko, M. L.; Kamińska, M.; Szymczyk, K.; Jędrzejczak, R. Levels of Selected Persistent Organic Pollutant (PCB, PBDE) and Pesticides in Honey Bee Pollen Sampled in Poland. PLoS ONE. 2016. 11(12):e0167487. https://doi.org/10.1371/journal.pone.0167487

58. Potts, S. G.; Biesmeijer, J.C.; Kremen, C.; Neumann, P.; Schweiger, O.; Kunin, W. E. Global pollinator declines: trends, impacts and drivers. Trends in Ecology \& Evolution. 2010. 25(6):345-353. https://doi.org/10.1016/j.tree.2010.01.007

59. Ruschioni, S.; Riolo, P.; Minuz, R. L.; Stefano, M.; Cannella, M.; Porrini, C.; Isidoro, N. Biomonitoring with Honeybees of Heavy Metals and Pesticides in Nature Reserves of the Marche Region (Italy). Biol Trace Elem Res. 2013. 154(2):226-233. doi: 10.1007/s12011-013-9732-

60. Costa, A.; Veca, M.; Barberis, M.; Tosti, A.; Notaro, G.; Nava, S.; Lazzari, M.; Agazzi, A.; Tangorra, F. M. Heavy metals on honeybees indicate their concentration in the atmosphere. A proof of concept. Italian Journal of Animal Science. 2019. 18(1):309-315. https://doi.org/10.1080/1828051X.2018.1520052

61. Orantes-Bermejo, F. J.; Pajuelo, A. G.; Megías, M. M.; Fernández-Píñar, C. T. Pesticide residue in beeswax and beebread samples collected from honey bee colonies (Apis mellifera L.) in Spain. Possible implications for bee losses. Journal of Apricultural Research. 2010. 49(3):243-250. https://doi.org/10.3896/IBRA.1.49.3.03

62. Mullin, C. A.; Frazier, M.; Frazier, J. L.; Ashcraft, S.; Simonds, R. High levels of miticides and agrochemicals in North American apiaries: implication for honey bee health. PloS ONE. 2010. 5(3). https://doi.org/10.1371/journal.pone.0009754 
63. Pettis, J. S.; Lichenberg, E. M.; Andree, M.; Stitzinger, J.; Rose, R.; Vanengelsdrop, D. 2013. Crop pollination exposes honey bees to pesticides which alter their susceptibility to the gut pathogen Nosema ceranae. PLoS One. 2013. 2013 (8). e70182. https://doi.org/10.1371/journal.pone.0070182

64. Wright, G. A. The role of dopamine and serotonin in conditioned food aversion learning in the honeybee. Commun Integr Biol. 2011. 4(3):318-320. doi: 10.4161/cib.4.3.14840

65. Hladun, K. R.; Smith, B. H.; Mustard, J. A.; Morton, R. R.; Trumble, J. T. Selenium toxicity to honey bee (Apis mellifera L.) pollinators: effects on behaviors and survival. PLoS One. 2012. 7(4):e34137. https://doi.org/10.1371/journal.pone.0034137

66. Klein, S.; Cabirol, A.; Devaud, J-M.; B. Barron, A.; Lihoreau, M. Review: Why Bees Are So Vulnerable to Environmental Stressors. Trends in Ecology \& Evolution. 2017. 32(4):11. doi: 10.1016/j.tree.2016.12.009

67. Peng, Y. -C.; Yang, E. C. Sublethal dosage of imidacloprid reduces the microglomerular density of honey bee mushroom bodies. Sci. Rep. 2016. 6. 19298-19311. https://doi.org/10.1038/srep19298

68. Gregorc, A.; Alburaki, M.; Rinderer, N.; Sampson, B.; Knight, P. R-.; Karim, S.; Adamczyk, J. Effects of comaphos and imidacloprid on honey bee (Hymenoptera: Apidae) lifespan and antioxidant gene regulations in laboratory experiments. Scientific Reports. 2018. 8(1):15003. doi: 10.1038/s41598-018-33348-4.

69. Raymann, K.; Motta, E. V. S.; Girard, C.; Riddington I. M-.; Dinser, J. A-.; Moran, N. A-. Imidacloprid Decreases Honey Bee Survival Rates but Does Not Affect the Gut Microbiome. Applied and Environmental Microbiology. 2018. 84 (13): e00545-18. https://doi.org/10.1128/aem.00545-18

70. Velemínsky, M.; Láznička, P.; Stary, P. Honeybees (Apis mellifera) as environmental monitors of heavy metals in Czechoslovakia. Acta Entomol. 1990. 87:37-44. ISSN 0001-5601

71. Naccari, C.; Macaluso, A.; Giangrosso, G.; Naccari, F.; Ferrantelli, V. Risk Assessment of Heavy Metals and Pesticides in Honey from Sicily (Italy). Journal of Food Research. 2014. 3(2):2014. DOI:10.5539/jfr.v3n2p107

72. Oroian, M.; Prisacaru, A.; Hretcanu, E. C.; Strone, S.-G.; Leahu, A.; Buculei, A. Heavy Metals Profile in Honey as a Potential Indicator of Botanical and Geographical Origin. International Journal of Food Properties. 2016. 19(8):1825-1836. https://doi.org/10.1080/10942912.2015.1107578

73. Formicki, G.; Greń, A.; Stawarz, A.; Zyśk, B.; Gal, A. Metal Content in Honey,Propolis, Wax and Bee Pollen and Implications for Metal Pollution Monitoring. Polish Journal of Environmental Studies. 2013. 22(1):99-106

74. Popov, B. B.; Hristova, V. K.; Presilski, S.; Shariati, M. A.; Najman, S. Assessment of heavy metals in propolis and soil from the Pelagonia region, Republic of Macedonia. Macedonian Journal of Chemistry and Chemical Engineering. 2017. 40. DOI:10.20450/mjcce.2017.

75. Matin, G.; Kargar, N.; Buyukisik, H. B. Bio-monitoring of cadmium, lead, arsenicand mercury in industrial districts of Izmir, Turkey by using honey bees, propolis and pine tree leaves. Ecological Engineering. 2016. 90(2016):331-335. https://doi.org/10.1016/j.ecoleng.2016.01.035

76. Nascimento, N. O.; Junior, N.; Oliveira, H. A.; de Abreu, F. A.; de Antonini, A. T.; Yasmine. Pollen storage by stingless bees as an environmental marker for metal contamination: spatial and temporal distribution of metal elements. Sociobiology. 2018. 65(259):2018. DOI: http://dx.doi.org/10.13102/sociobiology.v65i2.2078

77. Islam, M. N.; Khalil, M. I.; Islam, M. A.; Gan, S. H. 2014. Toxic compounds in honey. J. Appl Toxicol. 2014.34 (7):733-742. DOI: 10.1002/jay.2952 